\title{
Topical Anti-Inflammatory Activity of Bromelain
}

\author{
Elsa Badriyya, Salman, Amalia Refina Pratiwi, Dwisari Dillasamola, Yufri Aldi, Elidahanum Husni*
}

\section{Elsa Badriyya, Salman, Amalia \\ Refina Pratiwi, Dwisari \\ Dillasamola, Yufri Aldi, \\ Elidahanum Husni*}

Faculty of Pharmacy, University Andalas, INDONESIA.

\section{Correspondence \\ Elidahanum Husni}

Faculty of Pharmacy, University Andalas, INDONESIA.

E-mail: elidahanumhusni@phar.unand.ac.id History

- Submission Date: 18-08-2020;

- Review completed: 19-09-2020;

- Accepted Date: 01-10-2020.

DOI : 10.5530/pj.2020.12.217

Article Available online http://www.phcogj.com/v12/i6s

\section{Copyright}

(C) 2020 Phcogi.Com. This is an openaccess article distributed under the terms of the Creative Commons Attribution 4.0 International license.

\begin{abstract}
Introduction: Bromelain is a proteolytic enzyme found in pineapple plants. Aim: This study conducted to determine the activity of bromelain enzyme as an anti-inflammatory using the Granuloma Pouch method. Methods: The experimental animals were divided into five groups, namely the positive control group, the bromelain concentration group of $0.1 \% ; 0.5 \% ; 1 \%$, and the comparison group. Experimental animals induced carrageenan $2 \%$ subcutaneously. The dosage form is given topically for 2,4 , and 6 days. The observation was made by measuring the volume of edema, the total number, and the percentage of leukocyte cells on days 2,4 , and 6 . Results: The observation results of a positive control group, bromelain concentration $0.1 \%, 0.5 \%, 1 \%$, and the comparators, there was a significant decrease for the volume of exudate on days 2,4 , and $6(p<0.05)$. The average total number of leukocytes also decreased significantly $(p<0.05)$ in the positive control, the bromelain, and comparison group in day 2,4 , and 6 . At the same time, the mean leucocyte percentage had no effect ( $p>0.05)$. Conclusion: From the results of the study, it was concluded that the bromelain enzyme at concentration $0.1 \%, 0.5 \%$, and $1 \%$ have an anti-inflammatory effect by suppressing the volume of exudate, and the total number of leucocyte.
\end{abstract}

Key words: Anti-inflammatory, Bromelain, Exudate, Gel, Granuloma, Leukocyte.

\section{INTRODUCTION}

The immune system is a mechanism in a living creature that protects against the infection by identifying and killing pathogenic substances. The immune system consists of a complex network of cells, cytokines, lymphoid tissue, and organs, which work together in eliminating infectious material and other antigens. Important immune system cells concerning inflammation and the body's defense are neutrophils, eosinophils, basophils, mast cells, histiocyte cells, peripheral dendritic cells (DC), monocytes/macrophages, T cells, B cells, and NK cells. These cells have receptors that are molecules on the cell surface that can make cells interact with other molecules or cells. This receptor stimulation causes the activation and secretion of substances that increase the permeability and dilation of blood vessels, which is the beginning of the inflammatory response. ${ }^{1}$

In response to tissue injury, the body begins chemical signaling to heal the affected tissue. These signals activate the chemotaxis of leukocytes from the general circulation to the sites of damage. Activated leukocytes produce cytokines that induce an inflammatory response. ${ }^{2}$ Inflammatory cytokines released during the initial tissue injury response are tumor necrosis factor (TNF), interleukin 1 (IL-1) and interleukin 6 (IL-6). ${ }^{3}$ Cell damage that occurs due to inflammation of the cell membrane causes leukocytes to release the enzyme lysosomes and cyclooxygenase (COX) in arachidonic acid metabolism to produce prostaglandins which have various effects on blood vessels, nerve endings, and on cells involved in inflammation. ${ }^{4}$

In treating inflammation, people generally use nonsteroidal anti-inflammatory drugs (NSAIDs) and steroidal anti-inflammatory drugs. ${ }^{5}$ The public widely uses chemical anti-inflammatory drugs because they have a quick effect on removing inflammation but also have the risk of dangerous side effects. Nonsteroidal anti-inflammatory drugs (NSAIDs) can affect the production of gastric mucosa and interfere with cardiovascular and kidney function. ${ }^{6}$ While the use of steroidal antiinflammatory drugs is minimal for systemic purposes because of the high risk of side effects, especially in long-term use. ${ }^{7}$ Therefore, the utilization of plant nutritious substances with anti-inflammatory properties needs to be done to find alternative treatments with relatively smaller side effects. ${ }^{8}$

One of the nutritious substances of plants that act as an anti-inflammatory is the bromelain enzyme. Bromelain is known to have pharmacological activities, among others, as an antibiotic, antiinflammatory, anti-cancer, antithrombotic, and anticoagulant. ${ }^{9}$ Bromelain is a proteolytic enzyme found in pineapple stems (Ananas comosus (L.) Merr.). Bromelain is composed of the enzymes cysteine protease, peroxidase, acid phosphatase, amylase, and collagenase. This enzyme can break down proteins so that they break down proteins into amino acids that are more easily absorbed by the body..$^{10}$ In relation to anti-inflammation, bromelain plays a role by reducing the secretion of IL- $1 \beta$, IL6 , and TNF- $\alpha$ when immune cells are stimulated in inflammatory conditions due to cytokine production. ${ }^{11}$ Proteolytic enzymes for therapeutic purposes work by breaking down toxic substances and inflammatory agents as well as breaking down blood clots so that pain mediated by inflammatory agents is removed faster, and edema reduction occurs. ${ }^{12}$ 
Based on the description above, a study was conducted to see the activity of the bromelain enzyme as an anti-inflammatory in topical administration. The parameters observed in anti-inflammatory activity are by calculating the decrease in edema volume in mice, following the effect on the total number of leukocyte cells and the percentage of leukocyte cells in mice.

\section{MATERIAL AND METHOD}

\section{Place and time}

This research was conducted from January to March 2020 at the Laboratory of Research and Laboratory of Immunology and Serology, Faculty of Pharmacy, Andalas University.

\section{Tool}

The tools used were beaker (Iwaki), $5 \mathrm{~mL}$ syringe (One Med), $1 \mathrm{~mL}$ syringe (One Med), mortar and stamfer (PRC), slide glass (Deckglaser), centrifuge (Oregon), analytical scales (Ohaus), Brookfield viscometer (DV2T-RV), microscope (Zeiss), UV-Vis spectrophotometer (GenesysThermo scientific 10S UV VIS), hemocytometer (Assistent-Germany), $\mathrm{pH}$ meter (ATC ${ }^{\circledast}$ pen type $\mathrm{pH}$ meter), drop pipette, surgical scissors, animal cages, animal scales.

\section{Material}

The materials used were bromelain powder (Focusherb, FH20180715, Shaanxi Fuheng (FH) Biotechnology Co., Ltd, China), casein (BCBZ4643, Sigma-Aldrich), tyrosin (BCCB5514, Sigma-Aldrich), bovine serum albumin (030M1746, Sigma -Aldrich), trichloroacetic acid (HC54983730, Merck), carrageenan (C1138-100G, SigmaAldrich), Kaltrofen gel 2.5\% (Kalbe Farma, BN KCKTFB91417), carbopol 940 (CBM940-170219, Hangzhou Lingeba Technology Co., LTD, China), triethanolamine (D2823F, Petronas Chemicals), tween 80 (T0120 / 19, Brataco), glycerin (J0051 / 19, Brataco), aqua dest, methanol, Veet ${ }^{\oplus}$ feathering cream (Reckitt Benckiser Indonesia, BSGE414) and solvents Giemsa (HX73876504, Merck).

\section{Determination of Bromelain Enzyme Protein Levels}

Protein content was determined by the Biuret method at a wavelength of $547 \mathrm{~nm}$, and as a standard, a bovine serum albumin (BSA) solution was used with a variety of concentrations. The absorbance of the sample obtained is substituted on the y value of the standard BSA curve, so the $\mathrm{X}$ value is obtained which is the concentration of the sample protein. ${ }^{13}$

\section{Determination of Bromelain Enzyme Activity}

Enzyme activity was tested using the Murachi method through the casein digestion unit (CDU) using casein and L-tyrosine as substrates and standards. Testing is based on the case of proteolytic hydrolysis of casein by enzymes. Bromelain will hydrolyze casein to L-tyrosine. A standard curve is created by plotting the concentration of standard tyrosine solution on the $\mathrm{x}$-axis and absorbance on the $\mathrm{y}$-axis. ${ }^{9}$ The sample filtrate was measured for absorbance at a wavelength of 275 $\mathrm{nm}$. The absorbance of the sample is substituted on the y value of the tyrosine standard curve, then $\mathrm{x}$ is obtained which is the tyrosine concentration in sample. ${ }^{14}$

\section{Determination of Bromelain Enzyme Specific Activity}

The specific activity of the bromelain enzyme was calculated by determining the unit of enzyme activity divided by the enzyme protein level. ${ }^{15}$

$$
\text { Specific Activity }=\frac{\text { Proteolytic Activity }(\mathrm{U} / \mathrm{mL})}{\text { Protein levels }(\mathrm{mg} / \mathrm{mL})}
$$

\section{Preparation Sample}

Test preparations were made in the form of gel preparations made in four formulas, namely the base gel without the active substance and the bromelain enzyme gel formulated into a gel dosage form with several concentrations of $0.1 \%$; $0.5 \%$; and $1 \%$.

\section{Preparation Induction Solution}

Carrageenan $1 \mathrm{~g}$, crush it in the mortar and gradually add $50 \mathrm{~mL}$ of oleum sesame while crushed homogeneously so that the concentration of carrageenan obtained is $2 \%{ }^{16}$

\section{Anti-inflammatory Activity Testing with Granuloma Pouch Method}

Shaved the fur on the dorsal part of the mice with a diameter of \pm 3 $\mathrm{cm}$, carried out 24 hours before treatment. Injected the dorsal part of the mice with $5 \mathrm{~mL}$ air subcutaneously to form an airbag and, at the same time, also injected $0.1 \mathrm{~mL}$ carrageenan $2 \%$. After 24 hours, the airbag is formed, the air is sucked up with a $5 \mathrm{~mL}$ syringe so that the airbag becomes deflated. Then inject $0.5 \mathrm{~mL}$ carrageenan $2 \%$ solution to the dorsal part of the mice with the airbag. The test preparation is given by applying evenly to the area formed by the airbag, immediately after administration of $0.5 \mathrm{~mL}$ carrageenan. ${ }^{16}$ Each animal group was given the sample test, the positive control group was given a gel base without active substances, the test group was given $0.1 \%$ bromelain gel, $0.5 \%$ bromelain gel, and $1 \%$ bromelain gel, and the comparison group was given $2.5 \%$ ketoprofen gel. The test dosage was given as much as $0.2 \mathrm{~g}$ for each mice, and the test dosage was given for 2 days, 4 days and 6 days once a day. Exudate volume measurement is done on day 3 , day 5 , and day 7 . Exudate is taken by cutting the bag vertically and collected using a syringe and then measured in volume and calculated the percentage of inhibition of exudate formation.

$\%$ Inhibition of Exudate Formation $=\frac{V c-V u}{V c} \times 100 \%$

Note: $\mathrm{Vc}=$ Exudate volume of control animals

$\mathrm{Vu}=$ Exudate volume of the test animal

\section{Calculation the Percentage of Leukocyte Cells}

Percentage of leukocyte cells calculated by taking one drop of mice exudate on the object-glass and flatten it with another object-glass, then dry it. After dry, drip with methanol, so that the entire exudate is covered, leave on for 5 minutes. Then add one drop of Giemsa solution and leave it for 20 minutes. Wash with distilled water, dry, and look under a microscope with a magnification of $1000 \mathrm{x}$. Count the number of eosinophils, segment neutrophils, stem neutrophils, lymphocytes, and monocytes cells. ${ }^{17}$

\section{Calculation of Total Leukocytes}

A total number of leukocyte cells calculated by using the mice exudate with leukocyte pipettes. The mice exudate is sucked with leukocyte pipettes to mark 0.5 then suctioning Turk solution until mark 11 . Shake for 3 minutes then discard 1-2 drops. Drop the sample into the hemocytometer counting room with one drop of sample. Leave for 2 minutes for the leukocytes to settle. Calculate the number of leukocytes in the four corners of the calculated room with the formula ${ }^{18}$ :

Total leukocyte cells $=$ Number of Leukocyte Cells $x \frac{20}{0,4}$

\section{Data Analysis}

Edema volume data, total leukocyte cells data, percentage of the leukocyte cells data (eosinophils, stem neutrophils, neutrophil segments, monocytes, and lymphocytes), were analyzed statistically using two-way variation analysis (ANOVA) followed by Duncan's Test. ${ }^{18}$ 


\section{RESULTS AND DISCUSSION}

Before the formulation process begins, the protein content and specific activity of the Bromelain enzyme was determined. Determination of protein content was carried out using visible spectrophotometry, namely the Biuret method. The principle of the biuret method is the reaction of $\mathrm{Cu}+{ }^{2}$ with a protein peptide functional group, the formation of a complex between protein and $\mathrm{Cu}+{ }^{2}$ requires two peptide bonds to produce a purple chelate product whose intensity can be measured by a spectrophotometer ${ }^{20}$ The protein content is determined by comparing the absorbance of the bromelain enzyme with a curve standard bovine serum albumin (BSA). BSA solution has a maximum $\lambda$ of $547 \mathrm{~nm}$. From the BSA dilution series solution, a standard curve of bovine serum albumin (BSA) is obtained with a linear regression equation, namely $y=0.0001 x+0.0234$. The regression equation obtained is used to determine the protein content of the bromelain enzyme. The protein content of the pure bromelain enzyme was $2.73 \mathrm{mg} / \mathrm{mL}$.

Meanwhile, the proteolytic activity of the bromelain enzyme was determined by the Murachi method. The principle of this method is to determine the enzyme activity through the Casein Digestion Unit (CDU); it's using casein and L-tyrosine as substrates. Bromelain enzyme will hydrolyze casein to release L-tyrosine, one unit of enzyme proteolytic activity is defined as the amount of enzyme equivalent to $1 \mu \mathrm{g}$ tyrosine $/ \mathrm{min} / \mathrm{mL} .{ }^{9}$ L-tyrosine as a standard made a dilution series solution and measured the absorbance at a maximum $\lambda$ of 274 $\mathrm{nm}$, to obtain a linear regression equation $\mathrm{y}=0.0048 \mathrm{x}+0.103$. The proteolytic activity of the enzyme was determined by comparing the absorbance of the bromelain enzyme with a standard L-tyrosine curve. The proteolytic activity of the bromelain enzyme obtained is 90.37 $\mathrm{U} / \mathrm{mL}$. Meanwhile, the specific activity of the bromelain enzyme was determined by dividing the result of the proteolytic enzyme activity (U/ $\mathrm{mL}$ ) by the protein content $(\mathrm{mg} / \mathrm{mL})$, and the result was $33.15 \mathrm{U} / \mathrm{mg}$.

After measuring the anti-inflammatory activity of the bromelain gel, it can be seen the decrease in the volume of exudate in Figure 2. The largest percentage reduction in the average amount of exudate was $0.39 \mathrm{~mL}$ at the dosage of gel preparations with a bromelain enzyme concentration of $1 \%$. Besides that, the duration of using bromelain gel

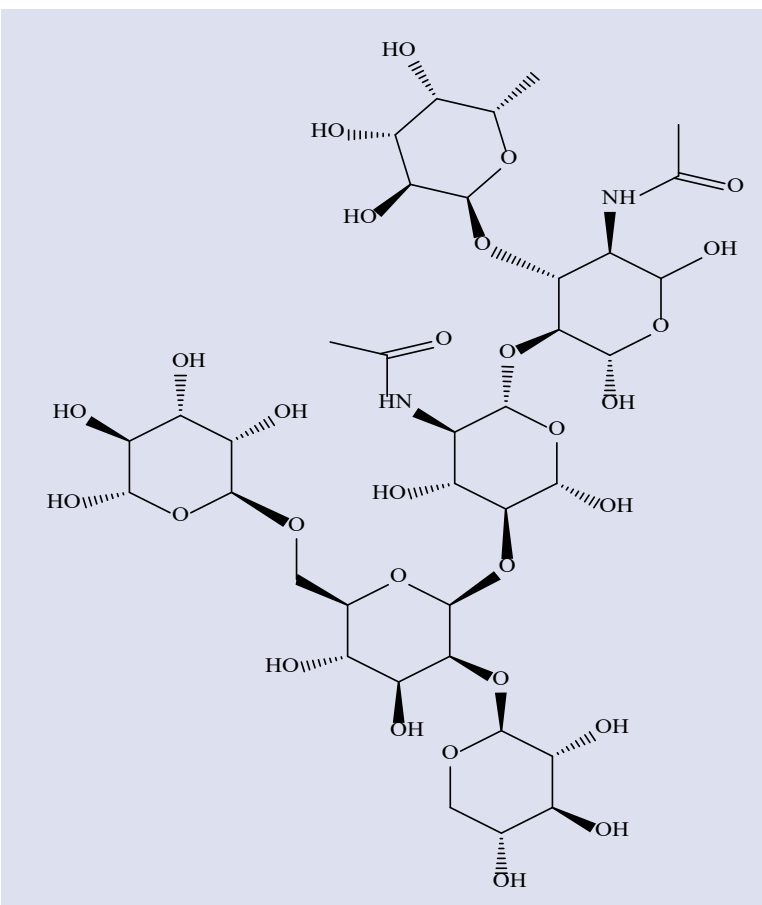

Figure 1: Chemical structure of the bromelain enzyme. with the greatest decrease in the volume of exudate, showed when it was using for six days with $0.45 \mathrm{~mL}$.

The calculation of the total leukocyte count of inflammatory mice showed a decrease in the total number of leukocytes from the five groups of experimental animals, which can be seen in Figure 3. The largest reduction in the total number of leukocytes for the test group was $7316.67 / \mu \mathrm{L}$ exudate in the $1 \%$ bromelain gel group with a duration of use for six days.

Statistical analysis of two-way ANOVA on variations in concentration and time on the decrease in exudate volume and total number of leukocytes showed significantly different results $(p<0.05)$. Then Duncan's test was carried out to see the differences between groups. The results of Duncan's test showed that the treatment group factors for the average volume of exudate and the total number of leukocytes, each test group gave different results with a significance value of 1,000 ( $p>0.05)$. Whereas for the difference in the time to use the preparation, the effect after using it for 4 days and 6 days has a significance value of 0.115 and 0.087 ( $p>0.05$ ). This means that the impact caused by the bromelain enzyme gel on day 4 and 6 days were the same.

Based on data on the decrease in the volume of exudate and the total number of leukocytes in inflammatory mice against the use of the bromelain enzyme topically, this is related to the stratum corneum layer in the epidermis of the skin which must be penetrated by the sample test in order to be adequately absorbed and produce anti-inflammatory effects. The stratum corneum of the epidermis of the skin is composed of its main component, a protein known as keratin. Bromelain as a proteolytic enzyme works by breaking down proteins into amino acids, so that when the bromelain gel is applied to the inflamed area, the skin pores are enlarged so the bromelain gel can be properly absorbed into the tissue. According to Rakte and Nanjwade (2014), bromelain has a proteolytic activity which is known to act as anti-inflammatory and anti-edema, bromelain helps break down toxic substances and inflammatory-causing agents and breaks up blood clots so that pain mediated by inflammatory agents is eliminated more quickly and edema is reduced. ${ }^{12}$

In addition to measuring the volume of exudate and the total number of leukocytes against inflammatory mice, the calculation of the types of leukocytes was also carried out. Photo of leukocyte cell types under a microscope can be seen in Figure 4, the leukocytes cells consist of eosinophils, basophils, neutrophils, lymphocytes, and monocytes. Data on the percentage of leukocytes types against the treatment group and the duration of use of the test preparation can be seen in the graphs shown in Figures 5 and 6.

Two-way ANOVA statistical analysis on the percentage of leukocyte cell types in the treatment group showed a significant effect on stem neutrophils, segment neutrophils, monocytes $(p<0.05)$, and insignificant for eosinophils and lymphocyte cells $(p>0,05)$. Meanwhile, for the duration of using the test substance, there was no significant effect on each type of leukocyte cells ( $\mathrm{p}>0.05$ ).

Leukocyte cells consisting of eosinophils, basophils, neutrophils, lymphocytes, and monocytes have different functions. The main purpose of leukocytes, in general, is as an immune system, but in each fraction of leukocytes, there is a different mechanism of action. Eosinophils are cells that play an essential role in response to diseases caused by parasites and allergies. While lymphocytes are cells that play an important role in responding to antigens by releasing antibodies. When inflammation occurs, a significant effect on the number of stem neutrophil cells, segment neutrophils, and monocytes is a form of body response. This occurs due to chemotaxis factors that cause leukocyte cells to go to the inflamed area. Neutrophils and monocytes are the most reactive cells to chemotaxis stimulation. Chemotaxis factors 


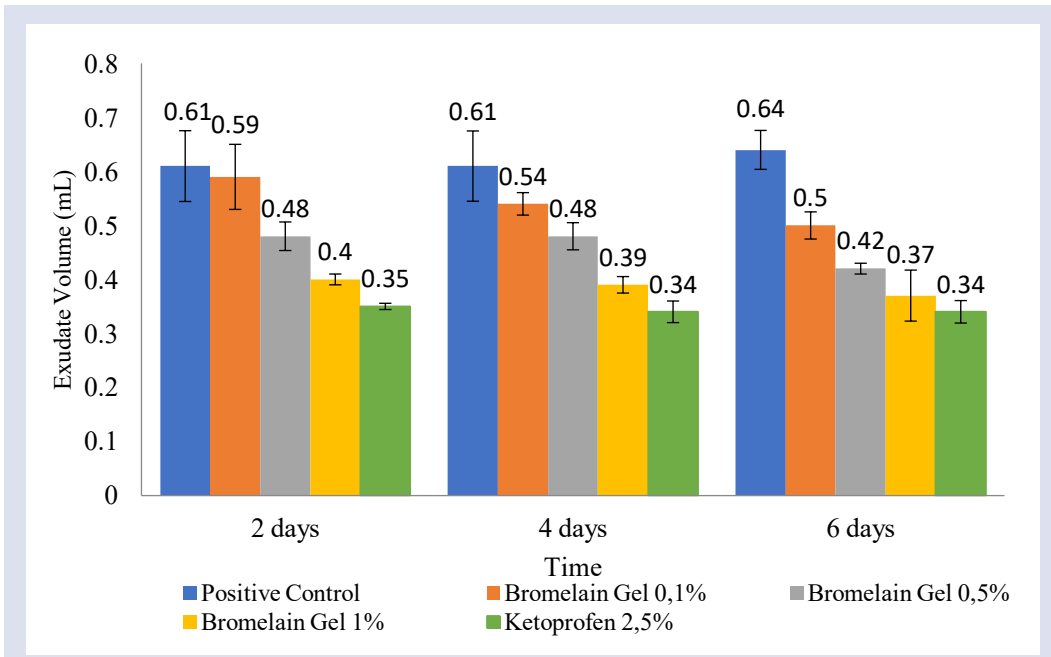

Figure 2: Graph of mean exudate volume after topical administration of bromelain gel in inflammatory mice.

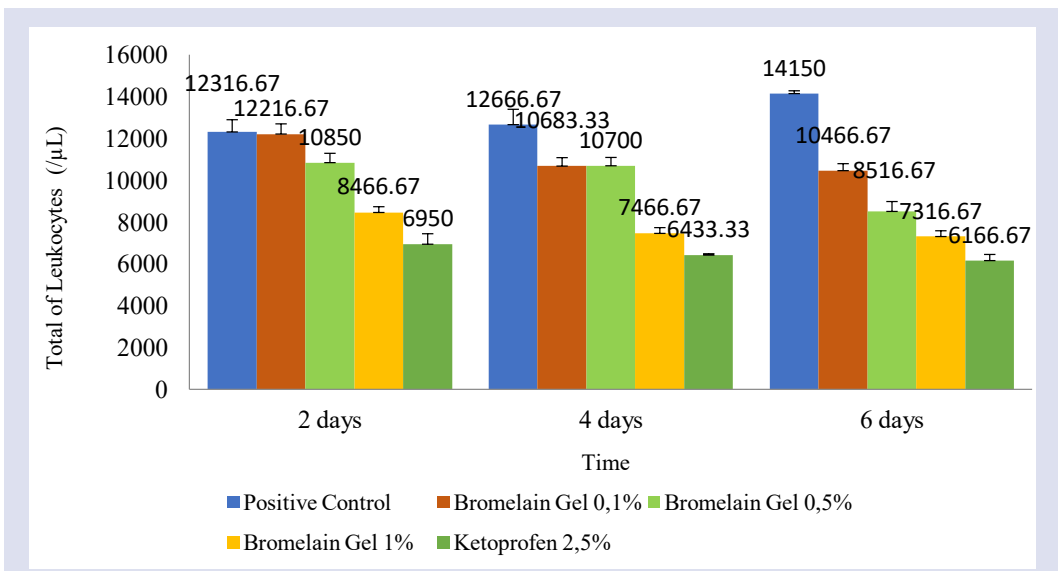

Figure 3: Graph of the mean total number of leukocytes after topical administration of bromelain gel in inflammatory mice.

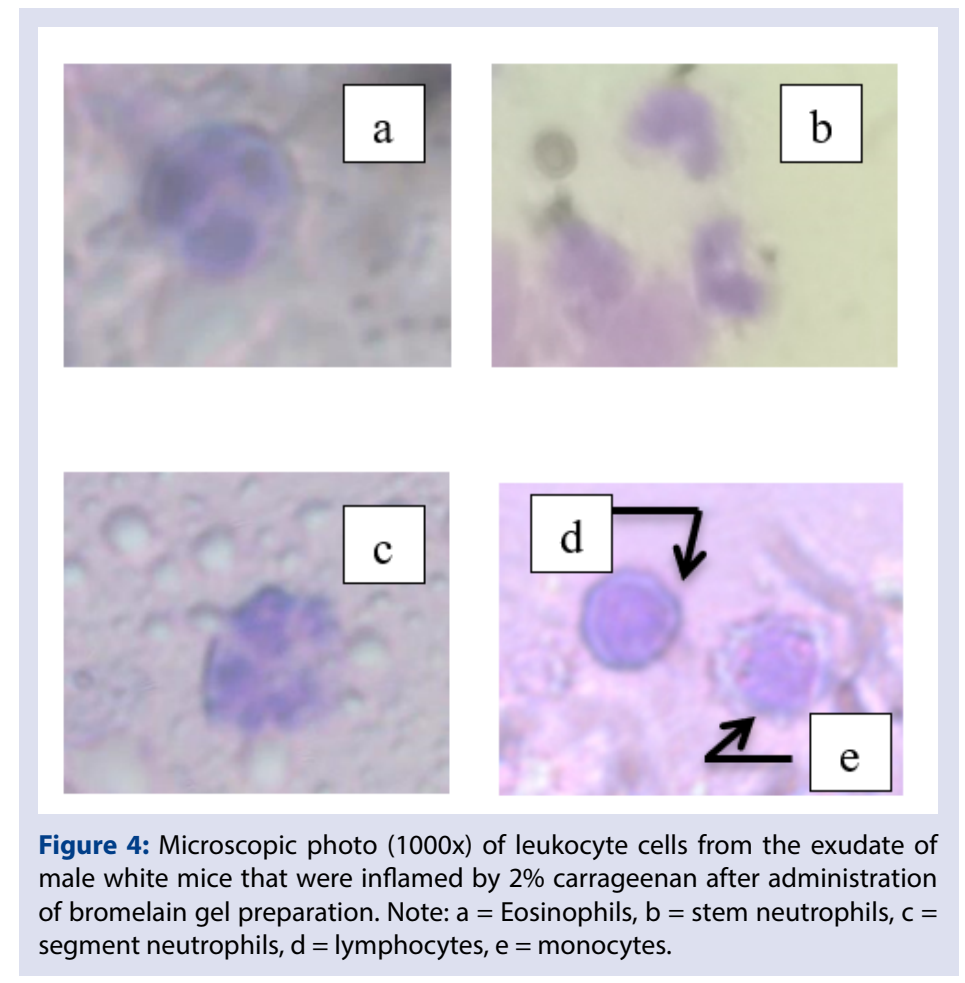




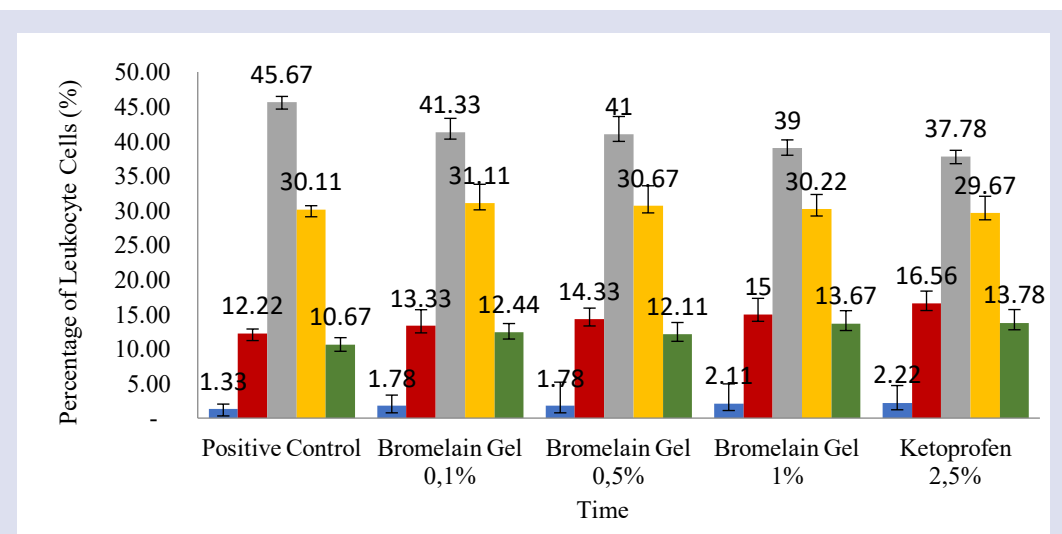

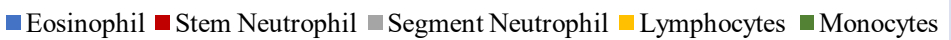

Figure 5: Graph of the relationship between the percentage of leukocyte cell types from exudate on the back of mice based on the treatment group after topical administration of bromelain gel.

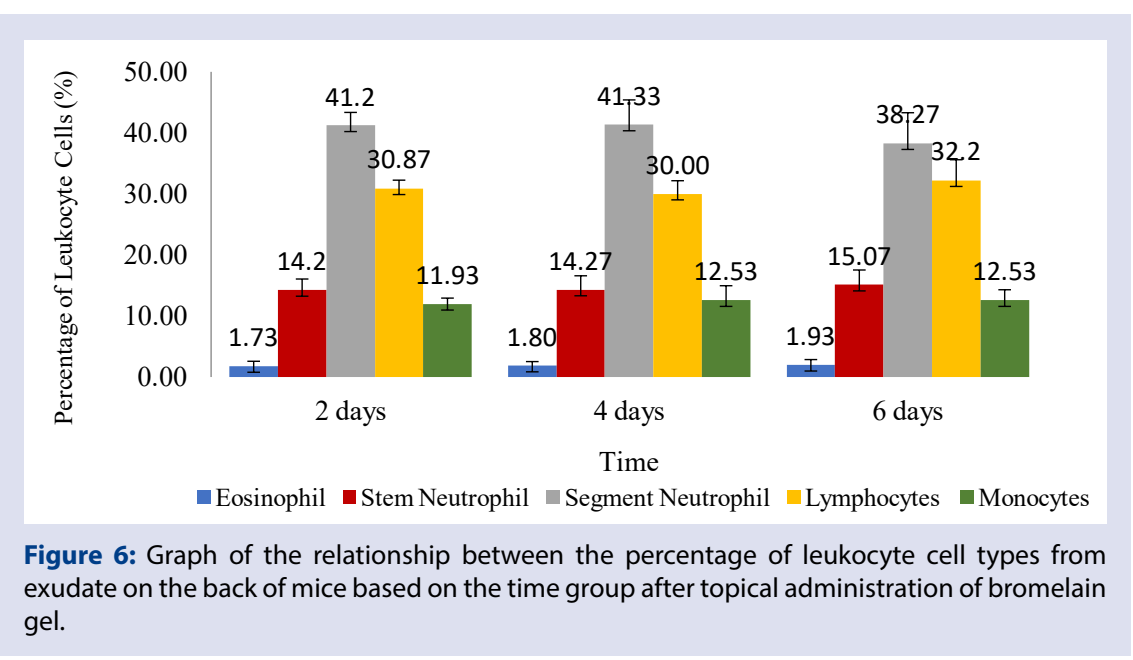

that can affect various kinds of neutrophils and monocytes, there are endogenous factors derived from plasma proteins or exogenous derived from bacterial products. When the inflammatory condition of neutrophil cells plays important role phagocytosis of bacteria and cellular debris, while monocytes are cells that will differentiate into macrophages into the inflammatory area to perform the phagocytic function. ${ }^{21}$

Duncan's test analysis showed that the treatment group factor and time to the percentage of segment neutrophil cells decreased significantly, but there was no decrease in the number of stem neutrophil cells. The number of segment neutrophils in Figure 5 is seen to increase in control animals and decrease in animals receiving the test sample. And for the duration of the observation shown in Figure 6, the number of segment neutrophils decreased significantly with increasing days. An increase in neutrophil cells at the beginning of inflammation occurs due to chemotaxis factors, where neutrophils will go to the inflamed area and attack pathogens. ${ }^{21}$ So that a gel sample test containing the bromelain enzyme can provide a restorative effect on inflammatory conditions resulting a decrease in the number of neutrophil cells which are leukocytes major role in the inflammatory response.

\section{CONCLUSION}

Based on the results of the anti-inflammatory activity test using the granuloma pouch method, it can be concluded that the use of $0.1 \%$ bromelain gel; $0.5 \%$; and $1 \%$ topically for 2,4 , and 6 days are able to provide anti-inflammatory effects. The largest decrease in exudate volume and total leukocyte count was shown by the use of $1 \%$ bromelain gel for 6 days. In addition, the percentage of leukocyte cell types also showed a decrease in the segmented neutrophil cells in inflammatory mice.

\section{ACKNOWLEDGEMENTS}

The authors would like to deliver a special appreciation to the Dean of Faculty of Pharmacy of Universitas Andalas for the financial support based on the Research Grant of faculty of Pharmacy Universitas Andalas.

\section{CONFLICTS OF INTEREST}

The author(s) declare(s) that there is no conflict of interest regarding the publication of this article.

\section{REFERENCES}

1. Sudiono J. Sistem Kekebalan Tubuh. Jakarta: Penerbit Buku Kedokteran EGC 2014.

2. Chen L, Deng H, Cui H, Fang J, Zuo Z. Inflammatory Responses and Inflammation-associated Diseases in Organs. Oncotarget. 2018;9(6):7204-18.

3. Marshall JS, Warrington R, Watson W, Kim HL. An Introduction to Immunology and Immunopathology. Allergy, Asthma Clin Immunol. 2018;14(s2):1-10.

4. Riansyah Y, Lanny M, Choesrina R. Uji Aktivitas Antiinflamasi Ekstrak Etanol Daun Ubi Jalar Ungu (Ipomoea Batatas (L.) Lamk) terhadap Tikus Wistar Jantan. Pros Penelit Spes Unisba. 2015:630-6. 
5. Wijaya L, Irsan S, Theodorus, Salni. Efek Antiinflamasi Fraksi Daun Andong (Cordyline Fruticosa L ) Pada Tikus Putih Jantan (Rattus Norvegicus) Galur Spraque Dawley. Biomed J Indones. 2015;1(1):16-24.

6. Moura MDG, Lopes LC, Silva MT, Barberato-filho S, Motta RHL, Bergamaschi C. Use of steroid and nonsteroidal anti-in flammatories in the treatment of rheumatoid arthritis. Medicine (Baltimore). 2018;97(41):1-6.

7. Kovacevic AB, Silva SMC, Doktorovova S. Anti-Inflammatory. Elsevier Inc.; 2018.

8. Pramitaningastuti A setyopuspito, Anggraeny EN. Uji Efektivitas Antiinflamasi Ekstrak Etanol Daun Srikaya (Annona squamosa. L) terhadap Edema Kaki Tikus Putih Jantan Galur Wistar. J IIm Farm. 2017;13(1)

9. Misran E, Idris A, Mat Sarip SH, Ya'akob H. Properties of bromelain extract from different parts of the pineapple variety Morris. Biocatal Agric Biotechnol. 2019;18.

10. Das S, Bhattacharyya D. Bromelain from pineapple: Its stability and therapeutic potentials. Trop Fruits From Cultiv to Consum Heal Benefits, Pineapple. 2017; (October 2017):43-100

11. Rathnavelu V, Alitheen NB, Sohila S, Kanagesan S, Ramesh R. Potential role of bromelain in clinical and therapeutic applications (Review). Biomed Reports. 2016;5(3):283-8.

12. Rakte A, Nanjwade B. Proteolytic Enzymes Delivery Systems: A Review. Int J Pharm Res Sch (IJPRS). 2014;3(2):671-7.
13. Wijaya JC, Yunianta Y. Pengaruh Penambahan Enzim Bromelin Terhadap Sifat Kimia dan Organoleptik Tempe Gembus (Kajian Konsentrasi dan Lama Inkubas dengan Enzim). J Pangan dan Agroindustri. 2015;3(1):96-106.

14. Ketnawa S, Chaiwut P, Rawdkuen S. Extraction of Bromelain from Pineapple Peels. Food Sci Technol Int. 2011;17(4):395-402.

15. Lehninger A. Principles of Biochemistry. New York: Worth Publisher; 1982.

16. Arifin $\mathrm{H}$, Silvia $\mathrm{R}$, Ifora. Efek Antiinflamasi Krim Ekstrak Etanol Daun Kirinyuh (Chromolaena odorata (L) R.M. King \& H. Rob ) Secara Topikal dan Penentuan Jumlah Sel Leukosit Pada Mencit Putih Jantan. J Farm Higea. 2017;9(1):68-76.

17. Aldi Y, Farhan I, Handayani D. Uji Aktivitas Beberapa Subfraksi Ekstrak Eti Asetat dari Herba Meniran (Phyllanthus niruri Linn.) Terhadap Titer Antibodi dan Jumlah Sel Leukosit Pada Mencit Putih Jantan. Pros Semin Nas dan Work Pelayanan Kefarmasian Herb Med. 2013:257-64.

18. Dillasamola D, Aldi Y, Kolobinti M. The Effect of Coriander Ethanol Extract (Coriandrum sativum L .) Against Phagocytosis Activity and Capacity of the Macrophage Cells and the Percentage of Leukocyte Cells in White Male Mice. Pharmacogn J. 2019;11(6):1290-8.

19. Azhar R, Ariyanto B, Umar S. Penentuan Parameter Fisika dan Kimia Bromelin Kasar Dari Batang Nanas (Ananas comosus Merr .). J Farm Higea. 2012;4(1):1-7.

20. Martina V, Vojtech K. A Comparison of Biuret, Lowry and Bradford Methods for Measuring the Egg's Protein. MendelNet. 2015:394-398.

21. Kumar V, Abbas A, Aster J. Robbins Basic Pathology. 9th editio. Philadelphia PA : Saunders.

\section{GRAPHICAL ABSTRACT}

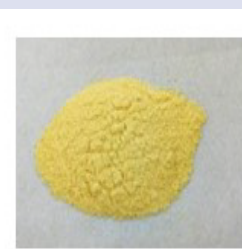

Bromelain Enzyme

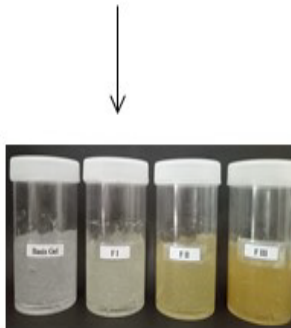

Sample preparation in the form of gel

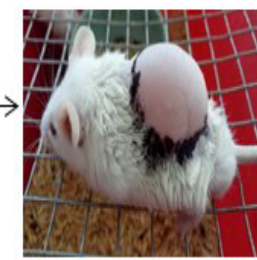

Anti-Inflammatory Activity Test at Five mice groups

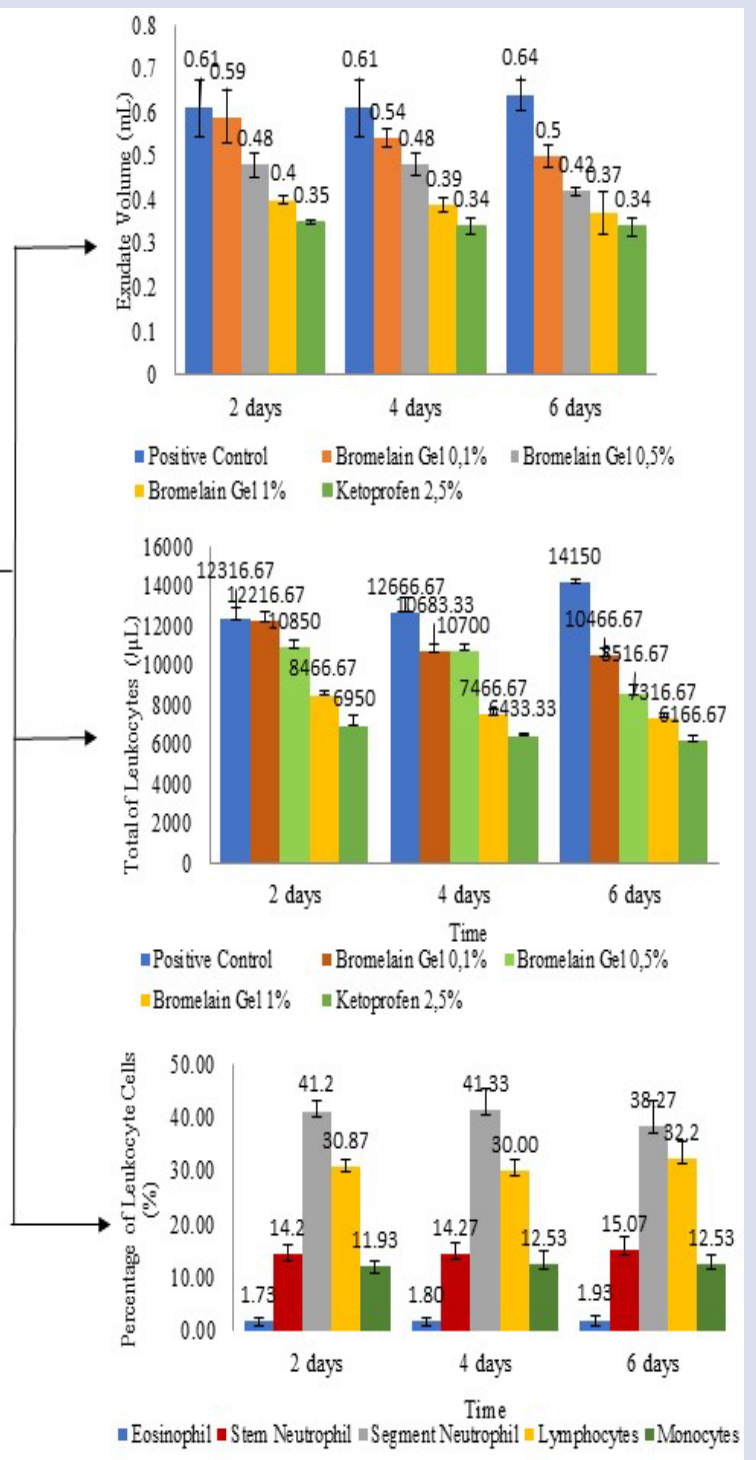




\section{SUMMARY}

Bromelain is a proteolytic enzyme found in pineapple (Ananas comosus (L.) Merr.). Bromelain enzymes are known to have several pharmacological activities including, antibiotics, anti-inflammatory, anti-cancer, antithrombotic, and anticoagulant. This study aims to determine the anti-inflammatory activity of bromelain topically from a gel formulation. Parameters observed included exudate volume, total leukocyte count, and percentage of leukocyte cell types from the exudate of inflammatory mice. The experimental animals were divided into five groups, namely the positive control group, the bromelain gel group with a concentration of $0.1 \% ; 0.5 \%$; $1 \%$, and the comparison group. Experimental animals induced carrageenan $2 \%$ subcutaneously. Sample test was administered topically for 2 , 4 , and 6 days. Based on the results of the two-way ANOVA statistical analysis and Duncan's test, the variation in concentration and time showed significant differences in exudate volume and total leukocytes $(\mathrm{p}<0.05)$. While the percentage of leukocytes at 2,4 , and 6 days showed no significant difference ( $p>0.05$ ), but there was a decrease in the number of neutrophil cells. From the granuloma pouch test, it can be concluded that the enzyme bromelain gel is concentrated at $0.1 \% ; 0.5 \%$; and $1 \%$ has an anti-inflammatory effect.

\section{ABOUT AUTHORS}

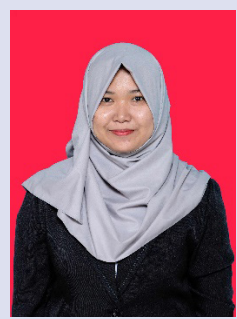

Elsa Badriyya, M. Si. Apt.: Currently a lecturer at the Faculty of Pharmacy, Andalas University. Graduated from the School of Pharmacy, Bandung Institute of Technology in 2016, then the Master's Program in 2017 at the Bandung Institute of Technology, School of Pharmacy. Currently working as a lecturer in Pharmacology and Clinical Pharmacy at the Faculty of Pharmacy, Andalas University.

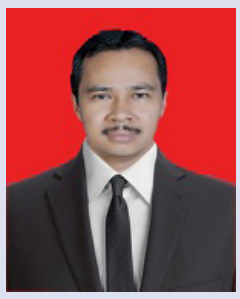

Dr. Salman, M.Si, Apt.: Currently as a lecturer at the Faculty of Pharmacy, Andalas University. Graduated from the Faculty of Pharmacy, Andalas University in 1990, then the Master's Program in 1995 at the Bandung Institute of Technology Pharmacy School (ITB) and the Doctoral Program in the Biomedical Department, Faculty of Medicine, Andalas University in 2015. Research and expertise in the field of Pharmaceutical Technology. Currently working as First Deputy Dean of the Faculty of Pharmacy, Andalas University.

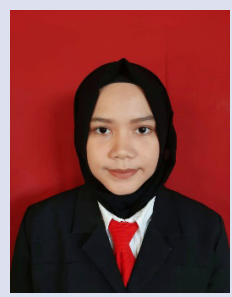

Amalia Refina Pratiwi : She is a student at the Faculty of Pharmacy, Andalas University, who has been involved in research that studies the anti-inflammatory activity of bromelain topically.

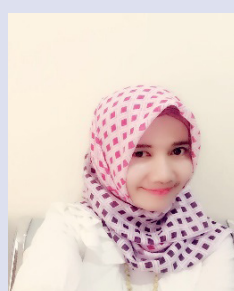

Dwisari Dillasamola, M.Farm, Apt.: Currently as a lecturer in a functional position at the Faculty of Pharmacy, Andalas University. Graduated from the Faculty of Pharmacy, Andalas University in 2004, then the Master's Program at Faculty of Pharmacy, Andalas University in 2011. Her research and expertise are in the field of Farmaco-Immunology. Currently working as a lecturer in Pharmaco-Immunology and Clinical Pharmacy at the Faculty of Pharmacy, Andalas University.

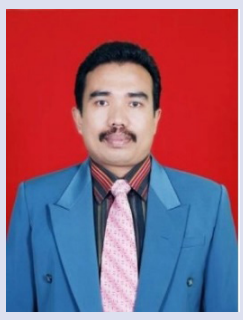

Prof. Dr. Yufri Aldi, M.Si, Apt.: Currently as a lecturer at the Faculty of Pharmacy, Andalas University. Graduated from the Faculty of Pharmacy, Andalas University in 1989, then the Master's Program in 1994 at the Bandung Institute of Technology School of Pharmacy (ITB) and the Doctoral Program in the Biomedical Department, Faculty of Medicine, Andalas University in 2013. Research and expertise in PharmacoImmunology. Currently working as Head of the Department of Pharmacy Doctoral Program, Faculty of Pharmacy, Andalas University. 


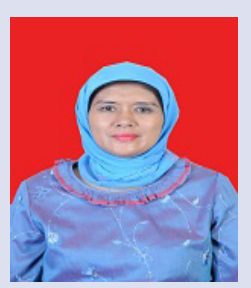

Dr. Elidahanum Husni, Apt.: Dr. Elidahanum Husni, M.Si, Apt.: Currently as a lecturer at the Faculty of Pharmacy, University Andalas. Graduated from Faculty of Pharmacy Universitas Andalas in 1986, then Master Program in 1995 at School of Pharmacy Bandung Institute of Technology and Doctoral Program in Department Biomedical, Faculty of Medicine, University Andalas in 2015. The research and expertise is Pharmacognosy

Cite this article: Badriyya E, Salman, Pratiwi AR, Dillasamola D, Aldi Y, Husni E. Topical Anti-Inflammatory Activity of Bromelain Pharmacogn J. 2020;12(6)Suppl:1586-93. 